\title{
SCIENTIFIC EXPERIMENTS ON ANIMALS and Constitutional Principle
}

\author{
Elaine L. Hughes
}

\section{INTRODUCTION}

It is a well-established principle that the division of powers in the Constitution Act, $1867^{1}$ sets out an exhaustive list of legislative subjects. ${ }^{2}$ Thus, all "new" subjects of potential regulation in Canada, such as biotechnology, must fit within the established categories of authority. This article explores some of the ethical implications of this constitutional framework and approach when the subject under consideration is the welfare of animals used in research.

\section{BACKGROUND}

Animal welfare legislation was first enacted in Britain $^{3}$ and British North America ${ }^{4}$ in 1822. In 1869 , shortly after Confederation, the first national anticruelty prohibitions were enacted in $\mathrm{Canada}^{5}$ and that same year the earliest Canadian humane society was founded in Montreal. ${ }^{6}$ Despite interest in the issue at a time of social development that included the abolition of slavery, prison and asylum reform, changes to child labour and welfare rules and various health care reforms, ${ }^{7}$ until the First World War the focus was primarily on working animals and blood sports $^{8}$ (although as early as 1876 Britain enacted legislation

Constitution Act, 1867 (U.K.), 30 \& 31 Vict., c. 3, reprinted in R.S.C. 1985, App. II, No. 5.

$2 \quad$ Ibid., ss. 91, 92, 92A and 95. See generally Ontario (A.G.) v. Canada (A.G) (Privy Council Appeals Reference), [1912] A.C. 571 (P.C.); Canada (A.G.) v. Ontario (A.G.) (Labour Conventions Reference), [1937] A.C. 326 (P.C.).

3 An Act to Prevent the Cruel and Improper Treatment of Cattle, 1822 (Martin's Act) (U.K.), 3 \& 4 Geo., c. 70.

4 According to C.D. Niven, History of the Humane Movement (London: Johnson, 1967) at 108, Nova Scotia passed the first North American anti-cruelty statute in 1822 .

An Act Respecting Cruelty to Animals, S.C. 1869 , c. 27.

6 Canadian Federation of Humane Societies, The Humane Movement in Canada (Ottawa: CFHS, n.d.) at 6.

G. Carson, Men, Beasts and Gods (New York: Scribner, 1972) at c. 5; S. Brooman \& D. Legge, Law Relating to Animals (London: Cavendish, 1997) at 40.

8 Alberta SPCA, The Animal Welfare Movement (Edmonton: Alberta SPCA, n.d.). specifically concerned with the use of animals in scientific experiments ${ }^{9}$ ).

Interest in the specific issue of vivisection did not reach the legislative agenda in North America, however, until a second era of massive social change the $1960 \mathrm{~s} .{ }^{10}$ Along with the civil rights, peace, and environmental movements came a second "stream" of animal advocacy in the form of proponents of animal rights. ${ }^{11}$ In addition, modern work on social violence has stimulated ongoing interest. ${ }^{12}$ Despite this interest, however, animal rights laws have never been enacted in Canada, and even more mundane efforts to regulate animal use and welfare are uneven, inconsistent and in some cases completely lacking. ${ }^{13}$ Long-overdue modernization of the basic anti-cruelty provisions of the Criminal Code is only now struggling through Parliament, ${ }^{14}$ while, as we shall see, national "control" over research animal use remains largely voluntary, and provincial rules, if any, are disparate and unevenly enforced. ${ }^{15}$

\section{EXPERIMENTS ON ANIMALS}

Accurate data about the number of animals used in research, and details about what experiments are taking

\footnotetext{
Brooman \& Legge, supra note 7 at 124-28.

10 The United States passed its first Animal Welfare Act in 1966. Canada formed an agency called the Canadian Council on Animal Care (CCAC) to oversee a voluntary system of "regulation" in 1968. Ibid. at 154-61.

11 See generally A.N. Rowan, Of Mice, Models and Men (Albany: State University of New York Press, 1984) at 251; E. Hughes \& C. Meyer, "Animal Welfare Law in Canada and Europe" (2000) 6 Animal L. 23 at 25-29

12 Hughes \& Meyer, ibid. at 31.

13 Ibid. at 35-40.

14 Bill C-10, An Act to amend the Criminal Code (cruelty to animals and firearms) and the Firearms Act, 2d Sess., 37th Parl., 2002 (as passed by the House of Commons 4 June 2002, with expectations of Senate amendments forthcoming).

15 L. Létourneau, "The Protection of Animals Used for the Purpose of Xenotransplantation in Canada" [unpublished, 2000, translated by author].
} 
place, is impossible to obtain in Canada. ${ }^{16}$ In part, this is because there is no national mandatory set of controlling regulations, nor reporting requirements, regarding animal use in research. Some national statistics are collected and published by the Canadian Council on Animal Care (CCAC), an independent agency that creates voluntary guidelines for research animal care; it also oversees and inspects participating institutions. ${ }^{17}$ Its approval is needed to obtain funding from major federal granting agencies (CIHR and NSERC) and, therefore, most university and government research complies with the CCAC system. However, in many parts of the country private laboratories are not compelled to join this system, so many do not, ${ }^{18}$ and university-private sector funding partnerships are also increasingly common. ${ }^{19}$

Nevertheless, the CCAC statistics give some notion of the extent of lab animal use in Canada. According to its most recent survey, ${ }^{20}$ the total number of animals used in 1999 (in laboratories it inspects) was $1,746,606$. Of these, 922,786 were used in basic research, ${ }^{21}$ or research on fundamental biology that consists of "knowledge without any immediate or beneficial application." "22 Another 55,267 were used for education or training, and 151,210 were used for "studies for the development of products or appliances for human or veterinary medicine." 23 A full 246,720 animals were used for "regulatory testing of products for the protection of humans, animals or the environment," ${ }^{24}$ a broad category which could include tests on anything from cosmetics to pulp mill effluent. Finally, 370,623 animals were used in applied research for "medical purposes, including veterinary medicine, that relate[s] to human or animal disease," ${ }^{25}$ i.e., for medical benefits "that portend some direct application to a problem in the immediate or reasonably foreseeable future." ${ }^{26}$ Thus, to the extent one can glean information from these reporting categories, approximately twentytwo percent of animals were being used in medical research while a much larger percentage were being

16 See generally C. Montgomery, Blood Relations: Animals, Humans and Politics (Toronto: Between the Lines, 2000) c. 3.

17 Canadian Council on Animal Care (CCAC), online: CCAC Homepage <www.ccac.ca>; Létourneau, supra note 15 at 1.1.1.

Montgomery, supra note 16 at $83,106$.

Ibid. at 105.

20 CCAC, Animal Use Survey - 1999, online: CCAC Homepage <www.ccac.ca/english/facts/facframeintro.htm> [hereinafter "1999 Survey"].

$21 \quad$ Ibid. at Table 3, "Purpose of Animal Use" (PAU) 1.

22 G.L. Francione, Animals, Property and the Law (Philadelphia: Temple University Press, 1995) at 167

"1999 Survey," supra note 20 at Table 3, PAU 4 and 5.

Ibid. at PAU 3.

Ibid. at PAU 2.

Francione, supra note 22 at 167. used for various types of product testing, other nonmedical scientific research, and for teaching.

What exactly is being done to these animals? There is no systematic way to obtain this information. Activists have reported details of a number of troubling studies over the years ${ }^{27}$ but in general the CCAC considers all information reported to it confidential or private. ${ }^{28}$ As Montgomery notes:

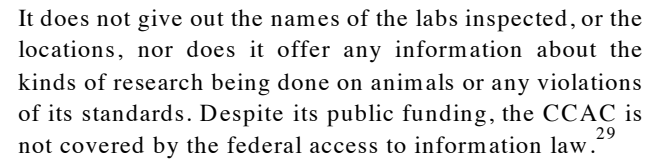

It does not give out the names of the labs inspected, or the locations, nor does it offer any information about the kinds of research being done on animals or any violations of its standards. Despite its public funding, the CCAC is not covered by the federal access to information law. ${ }^{29}$

One aspect of additional information in CCAC reports is a breakdown of the main species in use, and the "category of invasiveness" of the experiments done which, inter alia, must be in compliance with the CCAC's ethical and other guidelines. ${ }^{30}$ In 1999, 558,912 animals were used in category D procedures, being "experiments which cause moderate to severe distress or discomfort," ${ }^{31}$ while 58,828 animals were used in category E experiments "which cause severe pain near, at or above the pain threshold of unanesthetized conscious animals." Of the category E experiments, 48,095 were conducted for the "regulatory testing of products," 32 using more than ten times as many animals as were subjected to such experiments for applied medical research $(3,381) .^{33}$ Animals subjected to category E experiments (all uses) included fish, mice, rats, domestic birds, "farm animals" and rabbits. ${ }^{34}$

The CCAC statistics also reveal some trends in the scale of animal use for research. Older American statistics had suggested that public concerns about the use of research animals (coupled with high costs) had led to a decline in animal use over the years. ${ }^{35}$ The CCAC numbers have reflected this general trend,

27 See $e . g$. P.Singer, Animal Liberation (New York: Avon Books, 1975 ) c. 2; Francione, ibid. at 178-84; Montgomery, supra note 16 at c. 3 .

28 Montgomery, ibid. at 99-103.

29 Ibid. at 100.

30 CCAC, Ethics of Animal Investigation (1991), available on the CCAC website, supra note 17 , along with other guidelines on use, care, transgenics, endpoints and immunological procedures.

31 "1999 Survey," supra note 20 at Table 3. See also CCAC, Categories of Invasiveness in Animal Experiments (1991), available on the CCAC website, ibid.

"1999 Survey," ibid. at Table 3, PAU 3.

Ibid. at PAU 2.

Ibid. at Tables 4-7.

35 Francione, supra note 22 at 174 . Official CCAC policy is to follow the three "Rs" (reduce, refine, replace) to work toward lower numbers. See the CCAC website, supra note 17. 
showing total animal use declining from approximately 2.7 million in 1975 to 2.0 million in 1993 and 1.5 million in $1997 .{ }^{36}$ The recent explosion in biotechnology, however, seems to be reversing this trend internationally. Although the CCAC statistics do not include perhaps 100 private biotech labs, ${ }^{37}$ nor a number of labs that dropped out of the CCAC program during the $1990 \mathrm{~s}$ funding cuts, ${ }^{38}$ total animal use exceeded 1.7 million animals in 1998 and 1999, the most recent years for which data is available. In Britain, animal use was at an all time low by 1997 , but by 1998 a twenty-five percent increase in transgenics research pushed the lab animal total up for the "first general increase since 1976," ${ }^{39}$ and there is no reason to suspect a subsequent slowdown on either side of the Atlantic.

Public attempts to get additional details about research protocols have been in vain. ${ }^{40}$ In Ontario the only province with specific legislation designed to licence and inspect both private and public research laboratories ${ }^{41}$ - the practice is to release publicly only annual composite statistics similar to those compiled by the CCAC. ${ }^{42}$ Despite actions under provincial freedom of information laws, additional details about uses, locations and funding sources have not been provided by that province. ${ }^{43}$ Its denials of information requests have been based primarily on security concerns, or the notion that "disclosure could cause financial or scientific harm," reportedly due to fears of terrorism by animal rights extremists ${ }^{44}$ - although some of the institutions involved do release much of the information, piecemeal, in other ways. ${ }^{45}$

\section{POWER TO ACT}

Could we not enact national standards on laboratory animal care, or animal welfare generally? Alternatively, is there not a more active role for the provinces? Predictably, the division of powers in the Constitution Act, 1867, provides the foundation for any answer to these questions, yet since animal welfare generally (and scientific, medical and consumer research in particular) is not mentioned in the Constitution Act, 1867, governments must try to make these issues "fit" into the listed division of powers.

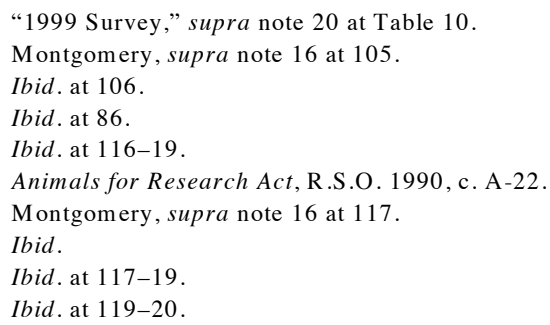

In our common law tradition, animals are property ${ }^{46}$ so provincial jurisdiction under the property and civil rights power is an obvious source of legislative jurisdiction. Most research institutes and universities will also fall within provincial control over intra-provincial works and undertakings and "local and private matters" within the province. In some cases powers to delegate to municipalities (e.g. pest control), powers over public lands (e.g. wildlife) and shared powers over agriculture (e.g. veterinary services) can all be relevant to aspects of animal welfare. ${ }^{47}$

Welfare concerns also "fit," however, within federal heads of power. The criminal law power supports general anti-cruelty prohibitions, and there is specific federal jurisdiction over particular kinds of animals (fisheries and migratory birds) and animals on federal property. For research animals, federal powers over trade and commerce and interprovincial works and undertakings are important, since most lab animals are imported from the United States. As well, the federal "spending power," as exercised through granting agency control and the CCAC system, is also critical. The concurrent power over agriculture (e.g. abbatoirs) and the potential - especially where there is a link to public health - for a matter to invoke the Peace, Order and Good Government powers (e.g. mad cow disease) might also be relevant. ${ }^{48}$

As is the case with other important matters not specifically mentioned in the division of powers sections of the Constitution Act, 1867 (such as public health and environmental protection) federal-provincial conflict is, perhaps, inevitable. A recent example is the Oncomouse case, ${ }^{49}$ decided in the fall of 2002 by the Supreme Court of Canada. In that case, the majority of the Court decided that genetically modified higher life forms were not "inventions" and, therefore, could not be patented under current law. Yet, although the Court noted that patenting is a form of property ownership, it did not examine the division of powers implications of

46 Domestic animals are chattels; wild animals are either Crown property (by statute) or become property upon capture. See B. Ziff, Principles of Property Law, 3d ed. (Toronto: Carswell, 2000) at 122 .

47 For a more detailed review of the division of powers arguments, see P. Wilson, Legal Opinion Letter Re: Legislative Jurisdiction Over Animals Used in Research, Teaching and Testing, prepared for the CCAC (26 November 1998), available on request from the CCAC; M. Hebert, Animal Protection: An Overview (Ottawa: Library of Parliament Research Branch, 1984).

48 Aboriginal jurisdictions over matters covered by treaties, selfgovernment agreements and other Aboriginal rights are also relevant to some welfare concerns (e.g. hunting), but not generally to the laboratory animal question.

49 The Commissioner of Patents v. The President and Fellows of Harvard College, 2002 SCC 76 [hereinafter Oncomouse case]. 
its suggestion that Parliament enact new legislation on the issue. Notwithstanding provincial control over "property," if Parliament now expands the patent rules then genetically modified plants and animals will be a special type of intellectual property prima facie within federal jurisdiction over "patents of invention and discovery." In addition, even as the Constitution enables government action, by outlining in broad terms who can regulate and what can be regulated (and thus, geographically to some extent it even tells us where the rules apply), it fails to provide precise limits or details. Those details must be filled in by negotiation, legislation and litigation. Finally, an obvious but often forgotten point is that the Constitution does not require action; nothing in it mandates that governments exercise their jurisdiction, nor does it provide guidance about when to act or how to address issues.

As we have seen in areas like environmental protection, this constitutional silence has a huge policy result. ${ }^{50}$ At one extreme, unclear jurisdiction can result in gaps or inaction, founded on the notion that the matter is outside that level of government's jurisdiction. At the opposite extreme, all levels of government might choose to act, resulting in duplication, overlap, inconsistencies and complaints by regulated industry about "excess regulation." This has typically led to

a wide range of adaptive techniques to avoid potential conflicts, referred to as 'cooperative' or 'executive' federalism. Examples ... include co-ordinated legislation, delegation of administrative functions, intergovernmental consultation, joint processes, and intergovernmental agreements. ${ }^{51}$

Recalcitrant adverse consequences of such approaches include delay, inefficiency, uncertainty, lack of uniformity, complexity, lack of transparency, unenforceability, overreliance on industry and inequity. ${ }^{52}$ The labyrinthine decision-making that often results not only frequently lacks credibility, but generally means that politically feasible - rather than ethically-based or scientifically sound - decisions are

50 See generally D.L. Van Nijnatten \& R. Boardman, eds., Canadian Environmental Policy: Context and Cases, $2 \mathrm{~d}$ ed. (Oxford: Oxford University Press, 2002); J. McKenzie, Environmental Politics in Canada (Oxford: Oxford University Press, 2002) c. 3.

51 M. Valiente, "Legal Foundations of Canadian Environmental Policy" in Van Nijnatten \& Boardman, eds., ibid., c. 1 at 8. See also A. Lucas, "Harmonization of Federal and Provincial Environmental Policies" in J.O. Saunders, ed., Managing Natural Resources in a Federal State (Toronto: Carswell, 1985) c. 2 .

52 See McKenzie, supra note 50; Van Nijnatten \& Boardman, supra note 50; E. Hughes, "Government Response to Environmental Issues: Institutional Inadequacies and Capacity for Change" (1990) 1:1 J. Env. L. \& Pract. 51. made. ${ }^{53}$ The lack of clear mechanisms for public participation in these processes and the associated lack of accountability for decisions are also factors in the frustration with the legal system which can lead to civil disobedience. ${ }^{54}$

While Canadian animal welfare law - both general anti-cruelty statutes and specific laboratory animal rules - is more rudimentary than our environmental law, it seems to suffer from the same debilitating uncertainties. Federally, the CCAC has been given a legal opinion suggesting national legislation could not be supported, ${ }^{55}$ so they are working on "universality" via mechanisms such as negotiation with provincial governments, and voluntary accreditation systems through the Standards Council of Canada. ${ }^{56}$ Thus, apart from rules on import and transportation, ${ }^{57}$ the only federal measures potentially applicable to research animal welfare are the general prohibitions against cruelty contained in the Criminal Code. ${ }^{58}$ Both the current $\operatorname{Code}^{59}$ and its proposed replacement ${ }^{60}$ prohibit the "unnecessary" suffering of animals. Arguably, any pain or suffering deemed necessary to achieve human goals can be justified under this rather vague standard, and critics have pointed to cases showing that practically any human use is, apparently, enough to warrant a finding of necessity. ${ }^{61}$ Certainly there is little likelihood that scientific, medical or even product-safety research would exceed this standard unless overtly cruel. ${ }^{62}$

Provincially, only six provinces have any degree of regulation specific to research animals. ${ }^{63}$ As mentioned previously, Ontario has a stand-alone statute which creates a system for licencing, inspecting and overseeing laboratories ${ }^{64}-$ a system which is understaffed and lightly enforced. ${ }^{65}$ Prince Edward

3 Ibid

54 T. Regan, Defending Animal Rights (Chicago: University of Illinois Press, 2001) at c. 7.

55 Wilson, supra note 47. Given the breadth of the criminal law power enunciated in R.v. Hydro-Québec, [1997] 3 S.C.R. 213, this opinion is qualified, even by its author.

56 Ibid.; CCAC, "1998 Motion on universality," online: CCAC Homepage <www.ccac.ca/ english/current/lega/en.htm>.

57 Health of Animals Act, S.C. 1990, c. 21.

58 Criminal Code, R.S.C. 1985, c. C-46, ss. $444-47$ (to be amended by Bill C-10, supra note 14).

59 Criminal Code, ibid., s. 446(1).

${ }_{60}$ Bill C-10, supra note 14, s. 182.2(1)(a).

${ }^{61}$ Francione, supra note 22 at c. 1; Hughes \& Meyer, supra note 11.

62 Francione, ibid. at c. 8; Montgomery, supra note 16.

${ }_{63}$ See Létourneau, supra note 15.

${ }_{64}$ Animals for Research Act, supra note 41.

65 Montgomery, supra note 16 at 104. 
Island has adopted the CCAC guidelines as law, ${ }^{66}$ and Alberta has a system that regulates universities only. ${ }^{67}$ Nova Scotia allows its provincial humane society to prescribe standards for laboratory animal care so long as they do not conflict with CCAC guidelines ${ }^{68}$ while both New Brunswick ${ }^{69}$ and Manitoba $^{70}$ make compliance with CCAC guidelines a defence to (or behaviour exempt from) cruelty charges under provincial law.

Any research outside of these partial proscriptions, and any research in other provinces or territories, is subject only to the Criminal Code or to general provincial anti-cruelty statutes. Not all provinces have general animal welfare legislation - for example, Quebec's statute ${ }^{71}$ has never been proclaimed in force. Other provincial law is limited - for example Ontario's statute establishes a humane society with intervention powers, but it contains no offence provisions nor penalties. ${ }^{72}$ Other documented weaknesses abound. ${ }^{73}$ Given the likely inapplicability of the Criminal Code, and the limitations of provincial law, in many cases animals are being "used in Canada with no oversight at all" and there is little apparent political will to alter the status quo in such a controversial area. ${ }^{74}$ Nothing in the division of powers in the Constitution Act, 1867 requires that this situation be remedied.

\section{REASON TO ACT}

The Constitution not only fails to guide governments about when or how to act, it also obscures the question of why we should act. The extant terminology of the division of powers sections can lead

66 Animal Health and Protection Act, R.S.P.E.I. 1988, c. A-11.1; Animal Protection Regulations, P.E.I. Reg. EC71/90

${ }^{67}$ Universities Act, R.S.A. 2000, c. U-3, s. 64; Animal Welfare Regulation, Alta. Reg. 221/2000

68 Animal Cruelty Prevention Act, S.N.S. 1996, c. 22, s. 22.

69 Society for the Prevention of Cruelty to Animals Act, R.S.N.B 1997, c. S-12, s. 12; General Regulation - Society for the Prevention of Cruelty to Animals Act, N.B. Reg. 2000-4, s. 4(2) and Sched. A.

70 Animal Care Act, S.M. 1996, c. 69; Animal Care Regulations, Man. Reg. 126/98.

71 Animal Health Protection Act, R.S.Q. 1977, c. P-42 Division IV .I.I (not proclaimed).

72 Ontario Society for the Prevention of Cruelty to Animals Act, R.S.O. 1990, c. O-36. The exception is the new s. 15.1, added in December 2002 by Bill 129, which creates offences for infractions by dog and cat breeders only.

73 Additional weaknesses of provincial anti-cruelty laws, such as exemptions and enforcement problems, are summarized in Hughes \& Meyer, supra note 11 .

74 Montgomery, supra note 16 at 105 . On the reluctance of government to tackle the more controversial aspects of animal welfare debates, see generally Hughes \& Meyer, ibid. at 41. us to frame our questions in a nearly predetermined way. Under the influence of the traditional approach, for example, we end up asking questions such as what kind of property an oncomouse will be - regular or intellectual - and in so doing, the Constitution arguably has us automatically thinking of animals in "mass terms." Adams explains the concept:

\begin{abstract}
Mass terms refer to things like water or colors; no matter how much you have of it, or what type of container it is in, water is still water. You can add a bucket of water to a pool of water without changing it at all. Objects referred to by mass term s have no individuality, no uniqueness, no specificity, no particularity. ${ }^{75}$
\end{abstract}

Thus, a mass term allows us to comfortably distance ourselves from thinking too deeply about the details of what we are doing, including the morality (or ethics) of our actions. Adams's example is our use of terms such as "meat" or "beef," which as she notes are literally pieces of "dead flesh of what was once a living, feeling being." "Y6 Yet by using a mass term that converts this unique individual into a "consumable thing," we disassociate ourselves from any difficulty we might have in accepting the "rightness" or palatability of the activity. ${ }^{77}$ Similarly, "property" and "humanity" as mass terms may historically have obscured the ethics of human slavery, and could well be obscuring our ability to think about whether non-human animals (or other components of nature) have individual rights or interests that demand our recognition. ${ }^{78}$

Arguably, our society does not see the "pith and substance" of animals as mere property, having rejected the Cartesian rationalist view of animals as insensate objects centuries ago.$^{79} \mathrm{We}$ know they differ from other chattels, like tables or cars, because they can suffer this is the raison d'être for nearly 200 years of animal welfare legislation. ${ }^{80}$ This distinction of animals from other property also serves as a foundation for the philosophical arguments that we should go beyond

75 C. Adams, Neither Man Nor Beast: Feminism and the Defence of Animals (New York: Continuum, 1995) c. 1 at 27.

76 Ibid. at 28.

77 Ibid. at 28-29. See also C. Adams, The Sexual Politics of Meat (New York: Continuum, 1990).

78 Francione, supra note 22 at $27-28$ and $110-12$; P. Williams, The Alchemy of Race and Rights (Cambridge: Harvard University Press, 1991) c. 8; C. Stone, "Should Trees Have Standing?" (1972) 45 U. S. Cal. L. Rev. 450; L. Tribe, "Ten Lessons our Constitutional Experience Can Teach Us About the Puzzle of Animal Rights: The Work of Steven M. Wise" (2001) 7 Animal L. 1.

79 For a history of the philosophic and scientific views of animals see Brooman \& Legge, supra note 7 at c. 1-2.

80 Summarized in the famous quote: "The question is not, Can they reason? nor, Can they talk? but, Can they suffer?" J. Bentham, The Principles of Morals and Legislation (1789) c. 17, s. 1 (see infra note 97 and accompanying text). 
"legal welfarism" to rethink the utilitarian balance between human uses and animal interests, ${ }^{81}$ or even to recognize animal rights, such as the right to life. ${ }^{82}$ Our shared ability to suffer is the key factor that creates the very debate about the degree of moral and legal consideration which we might ascribe to non-human animals. ${ }^{83}$

Is the potential suffering of laboratory animals not then something more than scientists manipulating their property? Scientific objectification and reductionism makes it hard to tell. In research, "“[1]aboratory animals' are a collectivity, depersonalized; they are studied en masse ${ }^{\not 84}$ as tools to generate data, or objects to be studied.$^{85}$ To many, this objectification of animals is at the foundation of animal abuse: "the attribution of deadness to what is alive, conscious, and sensitive involves a psychology of denial that conveniently facilitates the interests of the powerful." ${ }^{86} \mathrm{We}$ do not need to see the whole organism before us as a thinking and feeling individual - instead, the modern focus on biotechnology and genetics leads to an animal's reduction to constituent parts:

[A]s genetic and molecular reductionism have become so dominant, the organism has largely disappeared from the discourses of biology. ... Where once the phenotype the bodily and behavioral characteristics of the organism - was preeminent, now it is the genotype - the sum total of the genes. ${ }^{87}$

In this ideology, "the true essential quality, the very thing that makes a being itself" ${ }^{\prime 8}$ lies in its DNA. The

81 Francione, supra note 22 at 6; see also Singer, supra note 27.

82 See generally T. Regan, The Case for Animal Rights (Berkeley: University of California Press, 1983); S. Wise, Rattling the Cage: Toward Legal Rights for Animals (Cambridge: Perseus, 2000). Note that in Canadian constitutional tradition, even if animals were given some rights through the Charter of Rights and Freedoms, such rights would not be absolute, but could (like human rights) be subjected to "reasonable limits prescribed by law as can be demonstrably justified in a free and democratic society." Canadian Charter of Rights and Freedoms, s. 1, Part I of the Constitution Act, 1982, being Schedule B to the Canada Act 1982 (U.K.), 1982, c. 11;R. v. Oakes, [1986] 1 S.C.R. 103.

83 It is also the impetus behind those people, such as egoists, who argue we need not bother: J. Narveson, "Animal Rights" (1977) 7:1 Can. J. Phil. 161

${ }^{84}$ L. Birke, "Exploring the Boundaries: Feminism, Animals and Science" in C. Adams \& J. Donovan, eds., Animals and Women: Feminist Theoretical Explorations (Durham: Duke University Press, 1995) 32 at 41 [hereinafter Birke (1995)].

85 Ibid. See also Adams, supra note 75 at c. 2.

86 Adams \& Donovan, supra note 84 at 7-8.

87 L. Birke, Feminism and the Biological Body (New Jersey: Rutgers University Press, 2000) at 147 [hereinafter Birke (2000)].

88 B. Katz Rothman, "On Order" in M. Nussbaum \& C. Sunstein, eds., Clones and Clones (New York: W. Norton, 1998) 280 at 284. whole is nothing more than the sum of its parts, and these bits and pieces can be manipulated and controlled for human benefit, as in research with transgenic organisms.

In a recent documentary, ${ }^{89}$ an experiment was described in which a human gene was inserted into a potato to increase its heavy metal resistence. On a reductionist level, the single gene adds function, but it is just another protein, and we eat protein all the time. However, holistically - i.e., when we look at the whole integrated system - there are a host of troubling questions.$^{90}$ For a start, is this still a potato? Probably not - it could never (and did not ever) evolve in such a way. Is it even a plant, once it contains non-plant DNA? Who donated the human DNA and what degree of biological relationship now exists between the person and that potato? Are they now kin? Is the ingestion of such a potato a form of cannibalism?

Of course one of Charles Darwin's points was that we are, literally, kin to all other life on earth..$^{91}$ "Whatever the inhabitants of this world were before the publication of The Origin of the Species, they never could be anything since but a family." "92 This is part of the dilemma of vivisection - it is the similarity of nonhuman animals to human animals that is the primary reason to use them in research..$^{93}$ Yet at the same time their literal kinship and similarity must be denied; we must set ourselves apart from other animals and retain our false belief in "evolutionary discontinuity" to

\footnotetext{
elevate our own status, and as a corollary to reduce that of the 'others'. This is, we seek constantly to find new ways of shoring up the boundaries, and of attaching ethical significance to them. This is how we can justify using animals for our own ends in science and elsewhere. ${ }^{94}$
}

Yet scientific progress itself is bringing us closer to the need to confront such questions. As the Supreme Court of Canada noted in the Oncomouse case, there is an "increasingly blurred line between human beings and

The Genetic Takeover (National Film Board of Canada, 1999)

90 See generally G. Comstock, On the Ethical Case Against Agricultural Biotechnology (Norwell: Kluwer Academic, 2000); P. Thompson, "Ethics and the Genetic Engineering of Food Animals" (1997) 10 J. Ag. \& Environ. Ethics 1.

${ }_{91}$ See generally Brooman \& Legge, supra note 7 at 15-22.

92 J.H. Moore, The Universal Kinship, (Sussex: Centaur Press, 1906), as reprinted in Brooman \& Legge, ibid. at 17. See also B. Swimme, "How to Heal a Lobotomy" in I. Diamond \& G.F. Orenstein, eds., Reweaving the World (San Francisco: Sierra Books, 1990) 15 at 21-22, who notes: "everyone, utterly everyone, is kin."

93 Brooman \& Legge, ibid. at 18

94 Birke (1995), supra note 84 at 38. 
other life forms." ${ }^{95}$ If we take an animal such as a chimpanzee, which is already about ninety-eight percent genetically identical to us, and experiment on it, or first add some human DNA to it and then experiment on it, when does it become some type of proto-human slave? How long can we maintain a boundary of "otherness" between us and them, particularly when science is showing they have such "human" traits as capacity for language and other complex cognitive functions? ${ }^{96}$ What small differences will this boundary be based upon? Hairiness? skin color? nose width? To reiterate that which Bentham noted over 200 years ago:

[T] he blackness of the skin is no reason why a human being should be abandoned without redress to the caprice of a tormentor. It may come one day to be recognized, that the number of the legs, the villosity of the skin, or the termination of the os sacrum, are reasons equally insufficient for abandoning a sensitive being to the same fate ... [T] he question is not, Can they reason? nor, Can they talk? but, Can they suffer? ${ }^{97}$

\section{INTO THE FUTURE}

As biotechnology advances it is harder to hide from the moral quagmire under the mass term "animal." If we transplant a transgenic pig liver into a human, is that person no longer one-hundred percent human? If a transgenic chimp is ninety-nine percent genetically the same as us, but the transplant recipient is now, say, four percent pig, which chimera is "more animal"? Is our reaction to such questions to be governed simply by disgust? ${ }^{98}$ Or perhaps we will just dismiss the issue with a "blanket condemnation of all appeals to emotion" without regard for the legitimacy of the objections involved. ${ }^{99}$ If all lab animals are just transformable property, kinship precluded, the Constitution demands only that law-makers think about who has authority to control researchers (if they choose to think about this at all); does this constrain not only our ability to question the ethics of the actions, but whether science as practiced makes sense?

95 Oncomouse case, supra note 49 at para. 180

96 Ibid. at 46 . On the abilities of great apes see Wise, supra note 82.

97 Bentham, supra note 80 at c. 17 , s. 4, n. 1 [emphasis in original].

98 M. Midgley, "Biotechnology and Monstrosity" (2000) 30:5 Hastings Center Report 7. See also the Oncomouse case, supra note 49 , at para. $177-83$.

99 M. Nussbaum, "Secret Sewers of Vice: Disgust, Bodies and the Law" in S. Bandes, ed., The Passions of Law (New York: New York University Press, 1999) c. 1 at 21. See also ibid.; W.I. Miller, The Anatomy of Disgust (Cambridge: Harvard University Press, 1997) at c. 3; Birke (1995), supra note 84.
As numerous analysts have pointed out, "biologists know perfectly well that genes do not act in isolation." 100 Whole organisms are self-organizing, dynamic entities which interact (even at an embryonic and cellular level) with their environment through physiological and developmental processes, and the effects of random chance, so that not even clones are identical. ${ }^{101}$ The "biology that loses sight of the whole organism is one that permits a view of organisms as a set of replaceable parts" ${ }^{102}$ without intrinsic value and, perhaps dangerously, this thinking can undermine the way we conceptualize bodily integrity. ${ }^{103}$ Yet, short of human rights abuses such as coerced transplant "donations," we are loathe to reinvestigate other less reductionist, more descriptive areas of science, such as embryology, cognitive ethology, and natural history. ${ }^{104}$

One consequence of such unquestioning acceptance of the dominant genetic ideology is that it is nearly impossible to think non-hierarchically about nature and animals. It is a struggle to realize that even though humans are unique, "so are dogs, ostriches, and parrots, or anything else" ${ }^{105}$ and that difference does not equal superiority. In short, it is difficult to care about animals not just because they are like us, but to go further and care for them "because they are themselves." ${ }^{106}$ Why can we not simply let them be ${ }^{107}$ Even harder is to recall that "virtually all the actual experiences of this world, expressed through the manifest and mysterious characteristics of all the different beings," are simply absent from scientific literature. ${ }^{108}$ Hardest of all is to consider our extent of responsibility not only for the suffering of non-human animals, but for the "moral ecology" of dismissive and contemptuous attitudes toward welfare issues that some postmodern theorists suggest is one of humanity's most noticeable and unfortunate contributions to the range of all life experience. ${ }^{109}$

Such analyses, of course, still hover at the fringes of jurisprudential discussion, although there has been a substantial body of work amongst philosophers and

100 Birke (2000), supra note 87 at 139; and Midgley, supra note 98.

101 Birke (2000), ibid. at 138-76; Rothman, supra note 88 at 282.

102 Birke (2000), ibid. at 170.

103 Ibid. at 171; Midgley, supra note 98.

104 Birke (2000), ibid. at 140; Birke (1995), supra note 84 at 40-41.

105 Birke (1995), ibid. at 38

106 L. Vance, as quoted in S. Baker, The Postmodern Animal (London: Reaktion Books, 2000) at 174.

107 Baker, ibid. at 92-95 and 174-90.

108 K. Davis, "Thinking Like a Chicken: Farm Animals and the Feminine Connection" in Adams \& Donovan, supra note 84, c. 8 at 208 .

109 Ibid.; see also Midgley, supra note 98. 
ethicists on these issues in recent decades. ${ }^{110}$ In law, a current case ${ }^{111}$ is illustrative of the gap between theory and practice. In 1999, the Ontario Minister of Natural Resources cancelled that province's spring bear hunt in part because the spring hunt resulted in many orphaned cubs who die of starvation. A hunting group challenged the legislation that imposed the ban, alleging the Minister had no authority to act on the basis that such hunting practices were inhumane or unethical, and also alleging that the hunters' Charter rights to liberty (s. 7) and freedom of expression (s. 2(b)) were infringed by the ban. ${ }^{112}$ Given American jurisprudence on this issue - particularly in the area of legislation banning protests against hunting ${ }^{113}$ - the hunters had brief hope, quickly dashed when the Court of Appeal held that no justiciable constitutional issue was raised as there is no "right to hunt" contained in the Canadian Charter of Rights and Freedoms. ${ }^{114}$ Shortly thereafter, the Ontario legislature enacted a right-to-hunt statute, ${ }^{115}$ which will ensure an advisory commission guides the Minister's discretion about the use (killing for sport) of the Crown's property (wildlife).

\section{CONCLUSION}

A Constitution "is a piece of paper with words written on it."116 Many of those words, like "property," are arguably mass terms that obscure fundamental, difficult questions about what we, as a society, could fashion from that piece of paper. Other important words such as evolution, kinship, ethics and humanity, are not written on the paper at all, and perhaps can only be infused sideways into our deliberations, as water seeps toward the roots of a living tree. With the burgeoning biotechnology industry, however, these fundamental questions have a renewed urgency and currency. One can thus anticipate a challenging and controversial ongoing debate.

\section{Elaine L. Hughes}

Professor, Faculty of Law, University of Alberta

\footnotetext{
110 See generally Regan, supra note 54.

111 Ontario Federation of Anglers and Hunters v. Ontario (Minister of Natural Resources) (2002), 211 D.L.R. (4th) 741 (Ont. C.A.) [hereinafter $O F A H]$.

112 Charter of Rights and Freedoms, supra note 82.

113 M. Comninou, "Speech, Pornography and Hunting" in Adams \& Donovan, supra note 84, c. 5 .

114 OFAH, supra note 111.

115 Bill 135, Heritage Hunting and Fishing Act, 2002 (37th Leg., 3d Sess., Ont.), received royal assent on 27 June 2002; for a comment on the Bill see D. McLaren, "Angling for Control" (2002) 28:2 Alternatives 8

116 C. MacKinnon, Feminism Unmodified (Cambridge: Harvard University Press, 1987) at 206.
} 